\title{
CHANGES OF ORGANOLEPTIC QUALITY IN POTATO TUBERS AFTER APPLICATION OF NATURAL SPROUT INHIBITORS
}

\author{
Magdalena Grudzińska $^{\mathrm{a}^{*}}$, Zbigniew Czerko $^{\mathrm{a}}$, Monika Borowska-Komenda $^{\mathrm{b}}$ \\ ${ }^{a}$ Department of Potato Storage and Processing Plant Breeding and Acclimatization Institute, \\ Branch in Jadwisin \\ ${ }^{\mathrm{b}}$ Department of Soil Environment Sciences, Warsaw University of Life Sciences, Warsaw \\ "Corresponding author: e-mail: m.grudzinska@ihar.edu.pl
}

\begin{tabular}{|c|c|}
\hline ARTICLE INFO & ABSTRACT \\
\hline $\begin{array}{l}\text { Article history: } \\
\text { Received: August } 2015 \\
\text { Received in the revised form: } \\
\text { September } 2015 \\
\text { Accepted: October } 2015\end{array}$ & $\begin{array}{l}\text { The aim of this study was to evaluate changes in the sensory proper- } \\
\text { ties of the table potato in relation to the use of natural sprout inhibitors } \\
\text { during long-term storage. The material for the study consisted in four } \\
\text { varieties of potato of the medium early group. The research was } \\
\text { carried out in the Plant Breeding and Acclimatization Institute - }\end{array}$ \\
\hline $\begin{array}{l}\text { Key words: } \\
\text { organoleptic quality, } \\
\text { inhibitor sprouting, } \\
\text { potato, } \\
\text { storage }\end{array}$ & $\begin{array}{l}\text { harvest potatoes were stored from the end of October to April at } 5^{\circ} \mathrm{C} \text {, } \\
\text { at the relative humidity of } 90-95 \% \text {, without application of natural } \\
\text { sprout inhibitors (control) and using the natural sprout inhibitors } \\
\text { (essential oils). After storage, the potatoes were boiled and sensory } \\
\text { evaluation was carried out, which includes qualities such as: over- } \\
\text { cooking of the surface, texture, mealiness, flesh texture, taste and } \\
\text { smell. Study results showed that long-term storage of potatoes treated } \\
\text { with natural sprout inhibitors - peppermint, caraway and clove essen- } \\
\text { tial oils is significant for the changes in overcooking the surface, } \\
\text { structure of potatoes and mealiness of tubers after cooking. The taste } \\
\text { and smell of potato tubers depended only on the variety. }\end{array}$ \\
\hline
\end{tabular}

\section{Introduction and objective of study}

Food processing plants, which deal with separating potatoes for direct consumption, store raw material in temperatures of $4-5^{\circ} \mathrm{C}$. Within this scope of temperatures the period of physiological resting of tubers is longer than in case of tubers stored in higher temperatures $\left(8^{\circ} \mathrm{C}\right)$. For majority of potato cultivars, rest period of tubers starts in January - February and even in March which was proved by the research that has been carried out for years in the Physiology Laboratory and in the Potato Storage and Processing Centre, Branch in Jadwisin (Sowa-Niedziałkowska et al., 2002, 2005; Czerko et al., 2010; Zarzyńska, 2010). After the process of tubers sprouting has begun, their intensity of breathing and transpiration increases. These processes lead to the quantity and quality losses related to the turgor loss which negatively affects the sensory properties of raw material.

One of the properties of limiting this processes and maintaining relevant organoleptic properties of raw material is using chemical inhibitors of sprouts growth. CIPC (chlorproham) is a commonly applied chemical sprout inhibitor. Chlorproham may have alternatives 
Magdalena Grudzińska, Zbigniew Czerko, Monika Borowska-Komenda

in the form of natural substances - essential oils e.g. of mint pepper, caraway, clove, rosemary, fennel, which effectively limit tubers sprouting during storing (Kalt et al., 1999; Frazier et al., 2000; Cizkova et al., 2000; Czerko and Grudzińska, 2014; Gomes-Castillo et al., 2013; Costa et al., 2007).

Sensory properties are significant in case of edible potatoes stored since April particularly for producers who deal with selecting potatoes and for consumers who expect the highest possible quality of products which they buy.

Numerous scientific centres have undertaken research on the impact of natural sprouting inhibitors on the quality of potato fried products or on the quality of cooked potatoes (Kalt et al., 1998; Martin et al., 2011; Elbasier et al., 2011,2014; Grudzińska et al., 2012; Gomez - Castillo et al., 2013; Grudzińska and Zgórska, 2013). Current achievements proved that plant substances which limit potato sprouting do not determine the light colour of fried products (French fries, chips) and do not affect materially the taste and smell of cooked potatoes.

No studies have been carried out to indicate whether a repeated use of natural essential oils during potato storing influences changes of the sensory properties including: overcooking of the surface, pulp structure, consistency and mealiness of tubers after cooking.

The objective of the paper was to determine the sensory properties changes of potato tubers after cooking in relation to the applied natural sprout inhibitors during storing of raw material in temperature of $5^{\circ} \mathrm{C}$.

\section{Methodology of research}

Field and laboratory research were carried out in the Institute of Plant Cultivation and Acclimatization - National Research Institute Branch in Jadwisin in 2014-2015. Four cultivars of the table potato from the medium early group constituted the experimental material. Characteristic of the investigated varieties was presented in table 1. During the vegetation period the same agrotechnical treatments are performed in production plantations.

Table 1.

Characteristics of varieties of potato

\begin{tabular}{lccc}
\hline Cultivar & $\begin{array}{c}\text { Cooking } \\
\text { type }^{1}\end{array}$ & $\begin{array}{c}\text { Starch content } \\
(\%)\end{array}$ & $\begin{array}{c}\text { Dry matter content } \\
(\%)\end{array}$ \\
\hline Oberon & $\mathrm{B}$ & 12.00 & 19.10 \\
Bogatka & $\mathrm{B}-\mathrm{BC}$ & 9.45 & 17.10 \\
Malaga & $\mathrm{AB}$ & 10.80 & 19.00 \\
Jurata & $\mathrm{B}-\mathrm{BC}$ & 13.20 & 20.60 \\
\hline
\end{tabular}

${ }^{1}$ Culinary type: $\mathrm{A}$ - salad, $\mathrm{B}$ - general use; $\mathrm{C}$ - meal; $\mathrm{AB}, \mathrm{BC}$ - interim types

Directly after the harvest potatoes were placed in the experimental storage in the following conditions: in the preparatory period for the first two weeks after the yield, temperature of $15^{\circ} \mathrm{C}$ was maintained, at the relative humidity of $90-95 \%$; within the following two weeks the temperature was gradually decreased to $5^{\circ} \mathrm{C}$ maintaining the same humidity. The following combinations were used: potatoes were stored in the temperature of $5^{\circ} \mathrm{C}$, nontreated with the sprouts growth inhibitor - control sample; potatoes stored in the tempera- 
Changes of organoleptic quality...

ture of $5^{\circ} \mathrm{C}$ dressed with natural inhibitors (essential oils obtained from caraway, pepper mint, clove); concentration of active substance $-85 \%$. Potato tubers were treated with the use of fine-drops atomizer one time a month from December to April every 20 days from the moment of the end of dormancy (beginning of sprouting). A unit dose of the substance was $3.6 \mathrm{ml} \cdot 100^{-1} \mathrm{~kg}$ potatoes. Frequency of application resulted from intensity of tubers sprouting. The substance was applied as often as to inhibit the sprouts growth above $2 \mathrm{~mm}$.

After storing, the potato sample (ca. 20 tubers) from each cultivar and combination were washed and peeled with a slotted knife $(1.7 \mathrm{~mm})$. Peeled potatoes were cooked traditionally (in boiling water) until soft without salt. Cooking time approximately 900 (s).

Organoleptic assessment was carried out in the cooked potato tuber according to the instruction used by the Department for Cultivar Testing. The assessment covered the following properties: overcooking of the surface - tendency to falling apart in the $4^{\circ}$ scale (1- unchanged surface, 4 - overcooked cortical layer); consistency (compactness) - resistance to mechanical force in $4^{\circ}$ scale; $(1$ - compact, 4 - soft, tuber is falling apart); mealiness-tendency to falling apart in the $4^{\circ}$; scale $(1-$ non-meal; 4 - very meal); pulp structure - granularity in the $4^{\circ}$; scale (1- delicate, soft, 4 - coarse, fibrous); taste and smell (in the $9^{\circ}$ scale; $1,-1,-3$ a potato is not edible, $9-8$ a potato with a very good taste and good smell). A 5-person team of IHAR employees from the branch in Jadwisin carried out the assessment.

Non-parametric analysis of variance was used for determination of the significance of the impact of the investigated factors on the analysed properties. Kruska-Wallis test with Statistica 12 programme was applied for testing differences between average ranges.

\section{Analysis of results}

Table 2 presents the changes in overcooking of the surface of tubers of the investigated potato cultivars after cooking in relation to the applied natural sprout inhibitor.

Table 2.

Overcooked surface of potato tubers after storage of raw material at $5^{\circ} \mathrm{C}$ without application of sprout inhibitors (control) and with their use.

\begin{tabular}{lccccc}
\hline \multirow{2}{*}{ Cultivar } & \multirow{2}{*}{$\begin{array}{c}\text { Treated tubers } \\
(\text { control })\end{array}$} & \multicolumn{2}{c}{ Tubers treated with essential oils } & $\overline{\mathrm{X}}$ \\
\cline { 3 - 5 } & 1.0 & Peppermint & Caraway & Clove & 1.2 \\
\hline Oberon & 1.0 & 1.2 & 1.2 & 1.4 & 1.0 \\
Bogatka & 1.6 & 1.0 & 1.0 & 1.0 & 1.2 \\
Malaga & 1.2 & 2.8 & 1.4 & 1.0 & 1.8 \\
Jurata & 1.2 & 1.5 & 1.2 & 2.0 & \\
Average & $\alpha \leq 0.05$ & & & & \\
& Cultivar & $* * *$ & & & \\
& Treatment & $* *$ & & &
\end{tabular}


Magdalena Grudzińska, Zbigniew Czerko, Monika Borowska-Komenda

Statistical analysis of results proved significant variance of cultivars on account of the investigated property.

Bogatka tubers had an unchanged shiny surface as in a raw potato regardless the applied inhibitor (1 point). Jurata tubers have a slightly cracked, matt and less smooth surface of a potato after cooking (1.8 points). According to Leszczyński (2000), Kaaber (2001) starch, its content and granularity play a significant role in shaping this property. Too high content of starch worsens the overcooking degree because it swells and causes damage to cell structures (Jarvisa et al., 1992; Thybo et al., 2006). Treating potatoes with natural inhibitors materially influences the assessed property. Significant changes were observed in case of potatoes treated with peppermint essential oil (1.5 point). The overcooking of the surface of potatoes treated with caraway essential oil was identical with non-treated tubers (control sample). It was proved that treating Jurata potatoes with peppermint essential oil significantly deteriorates the overcooking of the surface of potatoes in comparison to the control sample. A tendency to overcooking of the surface of the pulp is related to saturation of the middle lamella of cell walls with pectin substances - protopectin and pectin which are water soluble. In the cell wall of plant tissue, the fraction which forms the middle lamella plays a stiffening and strengthening role (McComb and McCready, 1952). Bush and McCann (1999) add that the cell walls of potato tubers do not have a uniform structure and a pectin composition of wall is distributed spatially.

Table 3 presents the assessment of the pulp structure of cooked potato tubers after they were stored in the temperature of $5^{\circ} \mathrm{C}$ without the use and with the use of natural sprouting inhibitors.

Table 3.

The structure of cooked potato tubers after storage of raw material at the temperature of $5^{\circ} \mathrm{C}$ without application of sprout inhibitors (control) and with their use

\begin{tabular}{|c|c|c|c|c|c|}
\hline \multirow{2}{*}{ Cultivar } & \multirow{2}{*}{$\begin{array}{l}\text { Non-treated tubers } \\
\text { (control) }\end{array}$} & \multicolumn{3}{|c|}{ Tubers treated with essential oils } & \multirow{2}{*}{$\overline{\mathrm{X}}$} \\
\hline & & Peppermint & Caraway & Clove & \\
\hline Oberon & 1.8 & 2.0 & 2.6 & 1.8 & 2.0 \\
\hline Bogatka & 1.8 & 2.2 & 2.6 & 2.4 & 2.2 \\
\hline Malaga & 2.0 & 2.4 & 2.4 & 2.0 & 2.2 \\
\hline Jurata & 2.0 & 2.8 & 2.2 & 2.6 & 2.4 \\
\hline \multirow[t]{2}{*}{ Average } & 1.9 & 2.3 & 2.4 & 2.2 & \\
\hline & $\begin{array}{r}\text { NIR LSD } \alpha \leq 0.05 \\
\text { Cultivar } \\
\text { Treatment }\end{array}$ & $\begin{array}{c}* * \\
* * *\end{array}$ & & & \\
\hline
\end{tabular}

Explanatory notes: $\mathrm{n} . \mathrm{i}-$ not significant; $* * *$ very high significance

The presented studies prove that the cultivar and treating potato tubers during storage had a significant impact on the structure of cooked potatoes. Oberon and Bogatka cultivars not treated with sprouting inhibitors had the best structure (delicate and smooth) (1.8 point) and Jurata tubers treated with peppermint had a more rough structure ( 2.8 point). The use of natural substances deteriorated the structure of cooked potatoes of each cultivar. 
Changes of organoleptic quality...

Mealiness is related to overcooking of the surface and structure of potatoes. Mealiness or greasiness of cooked potatoes is frequently related to swelling and gelatinization of starch as well as strength of pectin compounds.

Potato tubers cultivar and treating with essential oils significantly affected the mealiness of cooked potatoes. Jurata tubers treated with caraway essential oil (3.0 point) were characterized with the highest mealiness and Malaga tubers non treated and treated with clove essential oil (1.6 point) were characterized with the lowest mealiness (table 4).

Table 4.

Mealiness of cooked potato tubers after storage of raw material at $5^{\circ} \mathrm{C}$, untreatment (control) and treatment natural inhibitors of sprouting

\begin{tabular}{lccccc}
\hline \multirow{2}{*}{ Cultivar } & \multirow{2}{*}{$\begin{array}{c}\text { Non-treated tubers } \\
\text { (control) }\end{array}$} & \multicolumn{2}{c}{ Tubers treated with essential oils } & \\
\cline { 3 - 5 } & & Peppermint & Caraway & Clove & $\mathrm{X}$ \\
\hline Oberon & 2.2 & 2.8 & 2.8 & 2.2 & 2.5 \\
Bogatka & 2.0 & 2.2 & 2.0 & 2.0 & 2.0 \\
Malaga & 1.6 & 1.8 & 2.0 & 1.6 & 1.7 \\
Jurata & 2.0 & 2.4 & 3.0 & 2.8 & 2.5 \\
Average & 1.9 & 2.4 & 2.1 & \\
\multicolumn{2}{c}{ NIR LSD $\alpha \leq 0,05$} & & & \\
& Cultivar & $* * *$ & & \\
\hline Treatment & $* *$ & &
\end{tabular}

Treating potatoes of four cultivars with natural inhibitors increased the mealiness of potatoes treated with peppermint and caraway in comparison to the control sample. Moreover, it was reported that treating potato tubers with clove essential oil for potatoes of three cultivars (Oberon, Bogatka and Malaga) did not affect the changes of the property in comparison to the control sample.

Consistency is one of the most important properties which influence the consumers' acceptance of potatoes for direct consumption. Proper consistency of potato tubers may be an effect of properly selected technological parameters in the production process (Rytel et al., 2006) but mainly of the quality and properties of raw material, which may be modified by environmental conditions during plant vegetation (Ciećko et al., 2005) and during storing (Grudzińska et al., 2004; Zgórska and Grudzińska 2012).

Table 5 presents the assessment of consistency of the cooked tubers of the investigated potato cultivars.

Application of essential oils as sprouting inhibitors does not affect significantly the assessed property. Consistency of cooked potatoes treated with natural sprouting inhibitors was correct, which means that tubers of the investigated cultivars had a quite compact consistency - they fell apart into two under a fork. According to Tajner-Czopek et al., (2002) consistency of potatoes after cooking depends on the cellulose, pectin, hemicellulose and lignine content, the amount of which in tubers may be regulated with the length of the vegetation period. The longer is the vegetation period the more content of cellulose, hemicellulose and lignine is found in potatoes. 
Magdalena Grudzińska, Zbigniew Czerko, Monika Borowska-Komenda

Table 5 .

The consistency of cooked potato tubers after storage of raw materials at $5^{\circ} \mathrm{C}$, without application of sprout inhibitors (control) and with their use

\begin{tabular}{lccccc}
\hline \multirow{2}{*}{ Cultivar } & \multirow{2}{*}{$\begin{array}{c}\text { Non-treated tubers } \\
(\text { control })\end{array}$} & \multicolumn{2}{c}{ Tubers treated with essential oils } & \\
\cline { 3 - 5 } & 2.2 & Peppermint & Caraway & Clove & $\mathrm{X}$ \\
\hline Oberon & 2.2 & 1.1 & 1.8 & 1.8 & 2.1 \\
Bogatka & 1.8 & 1.8 & 2.2 & 2.0 & 2.9 \\
Malaga & 1.4 & 2.0 & 2.2 & 2.0 & 2.0 \\
Jurata & 1.9 & 1.8 & 2.1 & 1.4 & 1.7 \\
Average & NIR LSD $\alpha \leq 0,05$ & & & & \\
& Cultivar & n.s & & & \\
& Treatment & n.s & & & \\
& & &
\end{tabular}

Explanatory notes: n.s - not significant;

The taste and smell of potatoes depends on the chemical composition. The excess of sugars and ash deteriorates the taste. On the other hand, free amino acids and nucleotides and vitamin $\mathrm{C}$ improve the taste. Glycoalkaloids influence this property unfavourably with a bitter taste (Lachman et al., 2001; Zgórska et al., 2006; Amer et al., 2014). In the presented research, Oberon and Malaga tubers had the best taste and proper smell (respectively 6.6 points; 6.5 points) (table 7), and Bogatka tubers were assessed the lowest (5.7 points).

Table 6.

Taste and smell of cooked potato tubers after storage of the raw material at $5^{\circ} \mathrm{C}$ without application sprout inhibitors (control) and with their use

\begin{tabular}{|c|c|c|c|c|c|}
\hline \multirow{2}{*}{ Cultivar } & \multirow{2}{*}{$\begin{array}{l}\text { Non-treated tubers } \\
\text { (control) }\end{array}$} & \multicolumn{3}{|c|}{ Tubers treated with essential oils } & \multirow[b]{2}{*}{$\overline{\mathrm{x}}$} \\
\hline & & Peppermint & Caraway & Clove & \\
\hline Oberon & 6.4 & 6.8 & 6.2 & 7.0 & 6.6 \\
\hline Bogatka & 5.6 & 5.6 & 6.0 & 5.8 & 5.7 \\
\hline Malaga & 6.8 & 6.8 & 6.2 & 6.4 & 6.5 \\
\hline Jurata & 6.6 & 5.6 & 6.6 & 5.6 & 6.1 \\
\hline Average & 6.3 & 6.2 & 6.2 & 6.2 & \\
\hline & $\begin{array}{r}\text { NIR LSD } \alpha \leq 0,05 \\
\text { Cultivar } \\
\text { treatment }\end{array}$ & $\begin{array}{l}* * * \\
\mathrm{n} . \mathrm{s} \\
\end{array}$ & & & \\
\hline
\end{tabular}

Explanatory notes: n.s - not significant; *** very high significance

Treating potatoes with natural essential oils did not have a significant effect on the change of the assessed properties (taste and smell) which confirmed the existing research results of Kalt et al., (1999), Cizkova et al., (2000), Martina et al., (2013), Gomes - Castillo et al., (2013) and Elbasir et al., (2011, 2014). 
Changes of organoleptic quality...

\section{Conclusions}

1. Taste and smell of potato tubers is a cultivar property which does not depend on natural sprouting inhibitors during storage

2. Natural sprouting inhibitors made of peppermint, clove and caraway may change the state of surface overcooking and mealiness of tubers of particular potato cultivars.

3. Regardless the applied natural essential oil, tubers of cultivar Bogatka had the best sensory properties after cooking. Natural caraway substance improved the sensory properties only in Jurata tubers.

\section{References}

Amer, F.S., Reddivari, L., Gaurav, P. Madiwale, G.P, Martha Stone, M., David, G. Holm, D.G, Vanamala, J. (2014). Effect of Genotype and Storage on Glycoalkaloid and Acrylamide Content and Sensory Attributes of Potato Chips. American Journal of Potato Research, 91, 632-641.

Bush, M.S., McCann, M.C. (1999) Pectic epitopes are differentially distributed in the cell walls of potato (Solanum tuberosum) tubers. Physiologia Plantarum, 107, 201-213.

Ciećko, Z., Rogozińska, I., Żołnowski, A.C., Wyszkowski, M. (2005). Oddziaływanie nawożenia potasem przy zróżnicowanych dawkach $\mathrm{N}$ i P na cechy kulinarne bulw ziemniaka. Biuletyn Instytutu Hodowli i Aklimatyzacji Roślin, 237-238, 151-159.

Cizkova, H., Vacek, J., Voldrich, M., Sevcik, R., Kratka, J. (2000). Caraway essential oil as potential inhibitor of potato sprouting. Journal Rostlinna Vyroba, 46, 501-507.

Costa, E Silva, Galhano, C.I.C., Moreira Da Silva, A.M.G. (2007). A new sprout inhibitor of potato tuber based on carvon/B-cyclodextrin inclusion compound, Journal of Inclusion Phenomena and Macrocyclic Chemistry, 57, 121-124.

Czerko, Z., Zgórska, K., Grudzińska, M. (2010). Czynniki ograniczające kiełkowanie ziemniaków podczas przechowywania, Zeszyty Problemowe. Postępów. Nauk Rolniczych, 577, 243-252.

Czerko, Z., Grudzińska, M., (2014). Wpływ warunków wegetacji i przechowywania na kiełkowanie bulw ziemniaka, Biuletyn Instytutu Hodowli i Aklimatyzacji Roślin, 271, 119-127.

ELbashir, H., A., Ahmed, A.,H., Yousif, K.S. (2011). Effect of Spearmint oil on sprouting and processing quality of Diamant and Sinora potato varieties, Current Research Journal of Biological Sciences, 3, 530-534.

ELbashir, H., A., Halim, A., Ahmed, R., Yousif, K.S. (2014). Efficacy of Different Applications of Spearmint Oil on Storability and Processing Quality of two Potato Varieties. Journal of Agriculture-Food and Applied Sciences, 2(5), 124-133.

Frazier, M.J., Kleikopf, G.E., Brandt, T.L. (2000). Spearmit oil and peppermint oil used as alternative sprout suppressants., American Journal of Potato Research,72, 737-747.

Gomez-Castillo, D., Cruz, E., Iguaz, A., Arroqui, C., Virseda, P. (2013). Effect of essential oils on sprout suppression and quality of potato cultivars, Postharvest Biology and Technology, 82, $15-21$.

Grudzińska, M., Starus, E., Zgórska, K. (2004). Ocena cech konsumpcyjnych bulw ziemniaka w czasie przechowywania. Inżynieria Rolnicza, 5(60), 127-146.

Grudzińska, M., Zgórska, K., Czerko, Z. (2012). Wpływ inhibitorów wzrostu kiełków na barwę frytek, Biuletyn Instytutu Hodowli i Aklimatyzacji Roślin, 265,149-156.

Grudzińska, M., Zgórska, K. (2013). Wpływ zastosowania S-karwonu jako naturalnego inhibitora wzrostu kiełków ziemniaka na jasność barwy chipsów ziemniaczanych, Żywność, Technologia, Jakość, 4(89), 161-169.

Jarvis, M.C., MacKenzie, E., Duncan, H.J. (1992). The textural analysis of cooked potato. 2. Swelling pressure of starch during gelatinisation. Potato Research, 35, 93-102. 
Kaaber, L., Brathen, E., Martinsen, B.K., Shomer, I., (2001). The effect of storage conditions on chemical content of raw potatoes and texture of cooked potatoes, Potato Research, 44, 153-163.

Lachman, J., Hamouz, K., Orsák, M., Pivec, V.(2001) Potato glycoalkaloids and their significance in plant protection and human nutrition. Journal Rostlinna Vyroba, 47, 181-191.

Leszczyński, W. (2000). Jakość ziemniaka konsumpcyjnego, Żywność. Nauka-Technologia-Jakość, Suplement, 4(25), 5-27.

Kalt, W., Prange, R.K., Daniels-Lake, B.J. (1999). Alternative compounds for the maintenance of processing quality of stored potatoes (Solanum tuberosum), Journal of Food Processing Preservation, 23, 71-81.

McComb, E.A., McCready, R.M. (1952). Colorimertic determination of pectic substance. Analytical Chemistry, 24, 1630-1632

Martin M., Galand, P., Bompeix, G., Beyssac, A. (2011) Mint oil: a new natural sprout suppressant opportunity. $18^{\text {th }}$ Triennial Conference of the European Association for Potato Research, Oulu, Finland, July 24-29, 105.

Rytel, E., Tajner-Czopek, A., Kita, A., Lisińska, G. (2006). Konsystencja ziemniaków gotowanych i produktów smażonych w zależności od zawartości polisacharydów. Zeszyty Problemowe Postępów Nauk Rolniczych, 511, 601-609.

Sowa-Niedziałkowska, G., Zgórska, K. (2005). Wpływ czynnika termicznego i odmianowego na zmiany ilościowe w czasie długotrwałego przechowywania bulw ziemniaka, Pamiętnik Puławski, $139,233-243$

Sowa-Niedziałkowska, G. (2002) Wpływ Naturalnych sposobów ograniczających intensywność przemian ilościowych w bulwach ziemniaka w czasie przechowywania, Zeszyty Problemowe Postęów. Nauk Rolniczych, 489, 355-364.

Tajner-Czopek, A., Kita, A., Rytel, E., Gołubowska, G. (2002) Zawartość polisacharydów nieskrobiowych i ligniny w bulwach ziemniaka o różnej długości okresu wegetacji. Zeszyty Problemowe Postępów Nauk Rolniczych, 489, 291-300.

Thybo, A.K., Christansen, J., Kaack, K., Petersen, M.A. (2006). Effect of cultivars, wound healing and storage on sensory quality and chemical components in pre-peeled potatoes. Lebensmitelwiss Technology, 39, 166-176.

Zarzyńska K. (2010) Odmianowe zróżnicowanie długości okresu spoczynku bulw ziemniaka. Ziemniak Polski, 3, 14-17.

Zgórska K., Z. Czerko, M. Grudzińska. (2006) Wpływ ekspozycji świetlnej na zielenienie, akumulację chlorofilu i glikoalkaloidów w bulwach ziemniaka, Żywność, Nauka, Technologia, Jakość, 1(46), 222-229.

Zgórska K., Grudzińska M., (2012). Zmiany wybranych cech jakości bulw ziemniaka w czasie przechowywania, Acta Agrophysica, 19, 203-214 
Changes of organoleptic quality...

\section{ZMIANY CECH SENSORYCZNYCH BULW ZIEMNIAKA PO ZASTOSOWANIU NATURALNYCH INHIBITORÓW KIEŁKOWANIA}

Streszczenie. Celem podjętych badań była ocena zmian cech sensorycznych ugotowanych bulw ziemniaka jadalnego $\mathrm{w}$ zależności po zastosowania naturalnych inhibitorów kiełkowania $\mathrm{w}$ czasie przechowywania surowca. Materiałem do badań były cztery odmiany ziemniaka $\mathrm{z}$ grupy średnio wczesnych. Badania prowadzono w Instytucie Hodowli i Aklimatyzacji Roślin - PIB Oddział w Jadwisinie w latach 2014-2015. Ziemniaki po zbiorze umieszczono w doświadczalnej przechowalni i przechowywano od października do końca kwietnia w temperaturze $5^{\circ} \mathrm{C}$, przy wilgotności względnej $90-95 \%$ bez stosowania naturalnych inhibitorów kiełkowania (próba kontrolna) oraz z zastosowaniem naturalnych inhibitorów kiełkowania (olejki eteryczne z: mięty pieprzowej, kminku i goździka). Po przechowywaniu, ziemniaki gotowano i wykonywano ocenę sensoryczną, w której uwzględniono takie cechy jak: rozgotowanie powierzchni, konsystencja, mączystość, struktura miąższu, smak i zapach. Oceny dokonywał 5-cio osobowy zespół. Na podstawie przeprowadzonej analizy wykazano, że zaprawianie bulw w czasie przechowywania naturalnymi inhibitorami kiełkowania - olejki eteryczne z mięty pieprzowej, kminku i goździka istotnie wpływa na zmiany rozgotowania powierzchni, struktury miąższu i mączystości bulw. Smak i zapach bulw ziemniaka jest cechą odmianową, niezależną od zastosowania inhibitorów.

Słowa kluczowe: ocena sensoryczna, naturalne inhibitory kiełkowania, ziemniak, przechowywanie 